University of Nebraska - Lincoln

DigitalCommons@University of Nebraska - Lincoln

1990

\title{
Predispersal Seed Predation, Postdispersal Seed Predation and Competition in the Recruitment of Seedlings of a Native Thistle in Sandhills Prairie
}

\author{
Svata M. Louda \\ University of Nebraska - Lincoln, slouda1@unl.edu \\ Martha A. Potvin \\ University of Nebraska - Lincoln \\ Sharon K. Collinge \\ University of Nebraska - Lincoln
}

Follow this and additional works at: https://digitalcommons.unl.edu/bioscilouda

Part of the Ecology and Evolutionary Biology Commons

Louda, Svata M.; Potvin, Martha A.; and Collinge, Sharon K., "Predispersal Seed Predation, Postdispersal Seed Predation and Competition in the Recruitment of Seedlings of a Native Thistle in Sandhills Prairie" (1990). Svata M. Louda Publications. 3.

https://digitalcommons.unl.edu/bioscilouda/3

This Article is brought to you for free and open access by the Papers in the Biological Sciences at DigitalCommons@University of Nebraska - Lincoln. It has been accepted for inclusion in Svata M. Louda Publications by an authorized administrator of DigitalCommons@University of Nebraska - Lincoln. 


\title{
Predispersal Seed Predation, Postdispersal Seed Predation and Competition in the Recruitment of Seedlings of a Native Thistle in Sandhills Prairie
}

\author{
SVAŤA M. LOUDA, MARTHA A. POTVIN ${ }^{1}$ AND SHARON K. COLLINGE ${ }^{2}$ \\ School of Biological Sciences, University of Nebraska, Lincoln 68588 and \\ Cedar Point Biological Station, Box 734, Ogallala, Nebraska 69153
}

\begin{abstract}
Platte thistle (Cirsium canescens Nutt.) is a native monocarpic plant species of Sandhills prairie. We concurrently tested three biological interactions that could influence its recruitment and population density: (1) predispersal flower and seed consumption by insects; (2) postdispersal loss of seeds to vertebrates, and (3) seedling competition with established plants. Few previous experimental studies have analyzed more than one of these processes at a time. Each interaction had a significant negative impact on seedling establishment. Insect seed predation caused major losses that were magnified in each succeeding life history stage. A 3-fold reduction in viable seeds by insects led to a 6-fold decrease in seedling establishment and a 6- to 37-fold reduction in the eventual number of new adults. Germination was low $(1.7 \%)$ and $80 \%$ of the seedlings were in exclosure cages, particularly in those cages placed in an open disturbed area instead of in the grassland. Competition between seedlings and established grasses led to a 9.5-fold decrease in seedling survival. Platte thistle populations were thus limited successively, first by seed predation and then by competition with established grasses. Both processes therefore reinforce selection for the fugitive life history observed in this species.
\end{abstract}

\section{INTRODUCTION}

Numerical patterns in plant populations are determined by the sum of births and immigrants, less the sum of deaths and emigrants. Biological interactions, such as competition and predation, have the potential to influence these fundamental demographic parameters. For a plant population to persist, individuals must produce viable seeds in spite of inflorescence-feeding insects, disperse and establish in spite of postdispersal seed feeders, and survive to maturity in spite of competitors and foliage-feeding herbivores (Harper, 1977; Louda, 1982a, b). However, the relative contribution of each of these sequential interactions is seldom studied simultaneously, especially experimentally in the field. In grasslands, few studies experimentally quantify the demographic parameters of native prairie plants, especially for nongrass herbaceous species. Yet, herbaceous species are important in most prairies (e.g., Weaver, 1965). Even fewer studies have simultaneously evaluated the contributions of competition and predation in the dynamics of native plants, including characteristic plants of prairie grasslands. Yet, both seed predation and competition are common and could be important in determining patterns of abundance in plant communities.

Seed predation is common in many systems and is frequently intense (Janzen, 1971). Many studies have quantified patterns of seed destruction (reviewed in Janzen, 1971; Crawley, 1983; Fenner, 1985; Foster, 1986; Price and Jenkins, 1987; Hendrix, 1989; Louda,

\footnotetext{
${ }^{1}$ Present address: Department of Biology, West Chester University, West Chester, Pennsylvania 19383

${ }^{2}$ Present address: Museum of Comparative Zoology, Harvard University, Cambridge, Massachusetts 02138
} 
1989). The most susceptible plant species tend to be relatively large-seeded and dependent on disturbance for population regeneration (Louda, 1989). However, most studies provide no information on the actual impact of the seed predation on the natural patterns of seedling establishment and of adult plant occurrence.

If seed damage is sufficient to restrict the number of seeds to less than the number of adults that could be sustained, then that damage will limit population size (Harper, 1977; Louda, 1982a, b). However, other factors, such as safe sites for germination, seedling competition and grazing, can also be important in limiting plant populations (Harper, 1977; White, 1980; Crawley, 1983, 1989; Fenner, 1985; Hendrix, 1989; Andersen, 1988, 1989; Louda, 1983, 1989). Thus, knowing that seed numbers are reduced severely by predation is not sufficient to predict the consequences for population size (Harper, 1977; Louda, 1982a; Andersen, 1989). The actual consequences of predispersal seed predation for population size were first tested quite recently, for two species of composites in coastal chaparral. Flower and seed destruction by insects limited the recruitment of both (Louda, 1982a, b, 1983), altered the gradient distribution of one (Louda, 1982b), and helped cause the replacement of one species by the other species along a climatic gradient from coast to mountains (Louda, 1982a, 1983, 1988). In order to assess the generality of these results and to evaluate contrasting conclusions from observational and experimental studies, similar tests need to be done for many species and in other ecosystems, such as in prairie grasslands.

In addition, competition can affect plant population dynamics. Strong competition among grasses has been demonstrated in prairies. Water availability often limits growth of the main prairie grasses (Barnes et al., 1984; Potvin and Harrison, 1984). And, competition can alter the survival of seedlings, in grasslands generally (e.g., Risser et al., 1981; Gurevitch, 1986) and in Sandhills prairie specifically (Potvin, 1984). Thus, competition among the new seedlings and between the new seedlings and established plants may influence plant demography, directly by reducing survival or indirectly by amplifying the negative impact of seed predation on the numbers of seedlings recruited.

The aim of this paper is to bring together data on the role of both predatory and competitive interactions on the dynamics of a native plant, the Platte thistle (Cirsium canescens Nutt., Asteraceae), in Sandhills prairie in western Nebraska. Several experiments were used to jointly evaluate the role of three potentially important interactions in the establishment and regeneration of Platte thistle. These concurrent experiments quantified the effects of: (a) predispersal flower and seed losses to insects; (b) postdispersal seed losses to seed-feeding vertebrates, and (c) seedling competition with established plants, particularly dominant grasses.

The results presented here summarize detailed data on the effect of feeding by insects on flowers and developing ovules to provide an initial answer to the question: do predispersal seed predators limit seed production enough to reduce the numbers of seedlings that establish? In addition, we present data to address two other questions on the relative influence of two other subsequent interactions. First, is feeding by vertebrates on seeds after their release from the plant important in limiting the number of seedlings in open disturbances or in grass vegetation? And, is competition with established grasses a factor in determining the number of new thistle individuals that become part of the population?

\section{METHODS}

Study system.-Arapaho Prairie is a 526-ha preserve of Sandhills vegetation in Arthur County of western Nebraska (Secs. 31, 32; T18N, R39W). It is representative of Sandhills prairie (Keeler et al., 1980). This prairie, which varies in relief from 1120-1190 m, has not been grazed since 1977 (Potvin and Harrison, 1984). Annual rainfall averages $40 \mathrm{~cm}$ 
(Lawson et al., 1977) and the soils are predominantly Valentine Fine (VaF) sand (U.S. Soil Conservation Service, 1977). The vegetation is a mixed grass prairie type, with a varied assemblage of plants that includes many sand specialists (Tolstead, 1942; Weaver, 1965; Keeler et al., 1980; Barnes et al., 1984).

Platte thistle, a monocarpic native species, occurs as a locally common weed in western Nebraska, southeastern Wyoming and eastern Colorado (Harrington, 1954; Lamp, 1980; Lamp and McCarty, 1981; Weber, 1987). This species matures in 3-5 years, flowers once and dies (Lamp and McCarty, 1981). The highest densities we observed were in washes or blowouts, the wind-maintained disturbances characteristic of Sandhills prairie (see Keeler et al., 1980).

Damage to developing seeds of Platte thistle can be extensive, ranging from $60-97 \%$ of the flower heads and 25-60\% of the immature seeds (Lamp, 1980; Lamp and McCarty, 1981, 1982a, b). The immatures of three native insects damage flowers and developing seeds: two picture-winged flies [Orellia occidentalis (Snow), Paracantha culta (Wiedmann): Tephritidae] and a small flower-infesting moth (Homeosoma stypticellum Grote: Pyralidae) (Lamp, 1980; Lamp and McCarty, 1981, 1982a, b).

A wide variety of vertebrates, including birds and various small mammals (A. Joern, pers. comm.), feed on the seeds of Platte thistle as they mature and are released from the plant. Densities of such seed-feeding vertebrates fluctuate but can be relatively high, especially in open areas (C. Lemen, pers. comm.). The seeds of Platte thistle may be particularly vulnerable to postdispersal predators as they are among the largest seeds found at Arapaho Prairie.

Experimental methods. - We did three concurrent experiments to test the effects of biological interactions in determining the probability of recruiting plants into populations of Platte thistle.

In the first experiment, we compared establishment of seedlings and subsequent survival to flowering adult plants, when seed loss by insects was reduced with insecticide versus when it was not reduced. In 1984 we found 12 areas containing maturing thistles; all maturing thistles were labeled and numbered. Two main treatments were assigned randomly between pairs of blowout areas with similar numbers of plants: (1) insecticide-in-water spray (Ortho "Isotox," with active ingredients O,S-dimethylacetyl-phosphate phoramidothioate ["Orthene," 8\%] and 1,1-bis(chlorophenyl)-2,2,2-trichloroethanol ["Kelthane," 3\%] and (2) water-only spray as a control for the application of water with the insecticide (Louda, 1982a, b, 1983; Andersen, 1988).

Blowout areas were considered blocks, with all maturing plants within a blowout receiving the same biweekly treatment. We treated plants within a blowout similarly in order to avoid confounding treatment outcomes if seedlings became established intermediate between two adult experimental plants within a blowout. Only developing flower heads were sprayed (25 May-31 July 1984). We left plants unsprayed in two additional areas as totally unmanipulated reference plants. In 1985, the treatments were repeated in the same areas, by reversing the treatment that maturing thistles received in areas used previously, and in several new areas. Over the 2 yr 11 areas (with 88 plants) received insecticide in water, 12 areas (with 75 plants) received water only, and eight areas (with 21 plants) were unmanipulated reference plots. The unbalanced design was used to maximize the power of the main contrast, performance of insecticided vs. noninsecticided plants, given a limited number of maturing thistles.

We counted the number of flowers initiated and the number of seeds matured by each plant in situ in late July. Following the seedling flush the following May, all seedlings in grids established around each treated plant were counted, marked and mapped. Grid size 
was increased in relation to adult plant density, and averaged $30 \mathrm{~m}^{2}$. In late May each year afterward (1985-1989) marked plants were recorded, until all had disappeared, died in place or flowered and died. The seed bank in the soil was estimated by sieving 20 surface soil samples $\left(900 \mathrm{~cm}^{2}, 8 \mathrm{~cm}\right.$ deep). Analysis of variance was used to evaluate the significance of overall treatment effects on the number of seeds, seedlings and adults. We used the Bonferroni correction to establish appropriate probability levels for tests involving sequential comparisons on the same group of plants over time.

In the second experiment, we excluded larger animals that feed on seeds after they are released from the parent plant. The three treatments were: full-cage exclosure, half-cage partial exclosure, and adjacent plots without a cage. The cages were $30 \times 30 \times 30 \mathrm{~cm}$ with an added $8 \mathrm{~cm}$ skirt sunk into the soil. Tops and all of the sides on the full cage and half of the sides on the partial cage were covered with $1.27 \mathrm{~cm}$ mesh hardware cloth. Adjacent $30 \times 30 \mathrm{~cm}$ plots were marked out and used as an unmanipulated reference treatment (=no cage). On 23 July 1984, 30 field-collected seeds were put into each cage, the equivalent of 333 seeds $/ \mathrm{m}^{2}$ and approximating expected densities in the proximity of large, successful plants. Half of the seeds in the cage were put on the surface and half were covered with 2 $\mathrm{mm}$ of sand. The design was blocked by location: two blocks of five replicates each were established. One block was put on the edge of a large blowout disturbance and the other was put amid grasses. Seedling emergence, survival, growth, and damage to leaves were recorded from September 1984 to May 1988. We used two-way ANOVA on square-root transformed data to evaluate the overall treatment and interaction effects, with subsequent one-way ANOVA of treatments for further analysis of significant habitat $\times$ location interactions. Since no differences in growth and damage were detected, we present only seedling numbers, the result of emergence and survival.

In the third experiment we transplanted naturally established seedlings. The two treatments were with and without close proximity to established grasses. On 25 May 1986, we established seven replicates of three seedlings per treatment. For each replicate we planted three seedlings into open areas within a clone of switchgrass (Panicum virgatum L.) and three seedlings into an adjacent open area between grass clones. Open areas within clones were $15-20 \mathrm{~cm}$ in diam; those between clones were at least $1.0-1.5 \mathrm{~m}$ wide bare areas. We planted each set of three seedlings $10 \mathrm{~cm}$ apart in an equilateral triangle. Plant size and survival were recorded after $9 \mathrm{wk}, 1 \mathrm{yr}$ and $2 \mathrm{yr}$. The data were analyzed using univariate ANOVA on the arcsine-transformed proportion surviving.

\section{RESULTS}

Seed losses to insects prior to seed release.-Comparing plant performance when seedfeeding insects were excluded from developing inflorescences, versus when they were not, showed three main results. First, plants usually developed and released very few viable seeds in the one reproductive event of their lifetime. Unsprayed reference plants averaged 32 viable seeds, only $5.6 \%$ of those initiated; and water-only sprayed plants averaged 41 $(7.1 \%)$ viable seeds, similar to unmanipulated reference plants (Table 1: t-test, $\mathrm{P}<0.05$ ).

Second, insect feeding caused a significant decrease in the number of viable seeds that actually matured, compared to the number that could have matured. Excluding flower- and seed-feeding insects caused a significant three-fold increase in the average number of viable seeds released by a plant (Table 1). Plants treated with insecticide more than doubled the average number and proportion of viable seeds matured and released, to 105 seeds (14.7\%). Variation in the number of viable seeds could not be explained by intrinsic differences among treatments since the numbers initiated were similar (Table 1).

Third, the insect-caused decrease in viable seeds caused at least a six-fold reduction in 
TABLE 1.-Seed production, seedling establishment and flowering by individuals of Platte thistle in the insecticide exclusion experiment (1984 and 1985 combined, $\mathrm{n}=$ number of experimental sites (blocks) at Arapaho Prairie) ${ }^{a}$

\begin{tabular}{|c|c|c|c|c|c|c|c|}
\hline & \multicolumn{2}{|c|}{$\begin{array}{l}\text { No spray } \\
(\mathrm{n}=8)\end{array}$} & \multicolumn{2}{|c|}{$\begin{array}{c}\text { Water } \\
(\mathrm{n}=12)\end{array}$} & \multicolumn{2}{|c|}{$\begin{array}{c}\text { Insecticide } \\
(\mathrm{n}=11)\end{array}$} & \multirow[b]{2}{*}{$\mathbf{P}$} \\
\hline & $\overline{\mathbf{x}}$ & SE & $\overline{\mathbf{x}}$ & SE & $\overline{\mathbf{x}}$ & SE & \\
\hline Total seeds initiated & 568 & $(66.9)$ & 577 & $(60.9)$ & 716 & $(77.9)$ & ns \\
\hline Viable seeds released & 32 & $(7.3)$ & 41 & $(5.6)$ & 105 & (11.2) & $0.001 *$ \\
\hline Seedlings established & 0.5 & $(0.15)$ & 0.5 & $(0.19)$ & 3.0 & $(0.48)$ & $0.001 *$ \\
\hline Adults matured ${ }^{b}$ & 0.01 & $(0.01)$ & 0.07 & $(0.03)$ & 0.37 & $(0.11)$ & $0.004^{*}$ \\
\hline
\end{tabular}

${ }^{a}$ Univariate ANOVA, ${ }^{*}=\mathrm{P} \leq 0.05$ as determined by using the Bonferroni method to correct for calculating expected probabilities for several sequential comparisons in time

${ }^{b}$ As of 22 May 1988

seedling establishment around adult plants (Table 1: $\mathrm{P}<0.01$ ). These differences could not be explained by variation in the seed bank; no viable thistle seeds were found in the soil samples in spite of an annual seed rain that averages four seeds $/ \mathrm{m}^{2}$ (Potvin, 1988). The reduction in seeds and then in seedlings led to significantly fewer adult plants (Table 1).

Seed losses to vertebrates after seed release.-Vertebrate seed-feeders did not exert a clearcut overall effect on seedling establishment in both habitats (Table 2). Two-way ANOVA showed a marginal treatment effect overall $(\mathrm{P}<0.10)$. However, both location $(\mathrm{P}<0.02)$ and the treatment $\times$ location interactions $(P<0.03)$ were significant. Higher seedling establishment occurred in full cage exclosures in the blowout habitat than in either the partial cage or the reference plot there (one-way ANOVA: $F_{2,5}=4.95, P<0.03$ ). In sum, postdispersal predation decreased establishment 9.5 -fold in blowouts, but made little difference to establishment of thistles in grass vegetation.

Second, the impact of vertebrate feeding was in addition to the effect of a very low germination rate, even among seeds with no evident signs of insect damage. The germination rate in full-cage exclosures was only $3.7 \%$. Overall, only $1.7 \%$ of the seeds placed in the plots $(\mathrm{n}=900)$ were observed as seedlings, and $80 \%$ of those were in the full-exclosure cages, especially those placed in the blowout area.

Seedling survival in relation to proximity to a grass clone. - Proximity to established grasses reduced seedling survival within $9 \mathrm{wk}$ (Table 3 ). ANOVA suggested that the initial decline

TABLE 2.-Total number of seedlings of Platte thistle observed in the test of the effect of postdispersal seed predation in seedling establishment using no-cage, partial-cage and full-cage exclosures in blowout and grass vegetation at Arapaho Prairie (August 1984-May 1988) ${ }^{a}$

\begin{tabular}{|c|c|c|c|c|}
\hline \multirow[b]{3}{*}{ Treatment } & \multicolumn{4}{|c|}{ Number of seedlings in: } \\
\hline & \multicolumn{2}{|c|}{ Blowout } & \multicolumn{2}{|c|}{ Grass } \\
\hline & $\overline{\mathbf{x}}$ & SE & $\overline{\mathbf{x}}$ & SE \\
\hline No cage & 0.01 & $(0.01)$ & 0.02 & $(0.02)$ \\
\hline Partial cage & 0.60 & $(0.40)$ & 0.02 & $(0.20)$ \\
\hline Full cage & 2.00 & $(0.84)$ & 0.01 & $(0.01)$ \\
\hline
\end{tabular}

${ }^{a}$ Two-way ANOVA: treatment effect $\mathrm{F}_{2,10}=2.53, \mathrm{P}<0.10$, location effect $\mathrm{F}_{1,10}=5.52, \mathrm{P}<0.02$, treatment $\times$ location interaction $\mathrm{F}_{1,10}=4.95, \mathrm{P}<0.03$ 
TABLE 3.-Survival of seedlings ( $\%$ of initial $n=21 /$ treatment) transplanted into open areas between or within clones of switchgrass (Panicum virgatum) at Arapaho Prairie (22 May 1986-20 May 1988) ${ }^{a}$

\begin{tabular}{|c|c|c|c|c|c|}
\hline \multirow[b]{2}{*}{ After } & \multicolumn{2}{|c|}{ In open } & \multicolumn{2}{|c|}{ In grass } & \multirow[b]{2}{*}{$\mathrm{P}$} \\
\hline & $\overline{\mathbf{x}}$ & SE & $\overline{\mathrm{x}}$ & $\mathrm{SE}$ & \\
\hline $9 \mathrm{wk}$ & 42.9 & 12.0 & 4.8 & 4.8 & 0.02 \\
\hline $1 \mathrm{yr}$ & 19.0 & 6.7 & 4.8 & 4.8 & 0.11 \\
\hline $2 \mathrm{yr}$ & 9.5 & 6.1 & 0.0 & 0.0 & 0.15 \\
\hline
\end{tabular}

${ }^{a}$ Univariate ANOVA on arcsine-transformed proportions

in the survival of thistle seedlings in grass clones was significant $(P<0.02)$. This could not be explained by initial seedling size since no significant differences between treatments occurred, in number of leaves, length of longest leaf, or root length $(P>0.15)$. The difference between the treatments persisted after $2 \mathrm{yr}$, but decreased in statistical significance with time $(\mathrm{P}<0.11$ after $1 \mathrm{yr}, \mathrm{P}<0.15$ after $2 \mathrm{yr})$. The decrease in significance may reflect small sample sizes; mortality reduced the number of seedlings severely, especially in the grass. After $1 \mathrm{yr}$ only four seedlings remained in the open and one in the grass and by the end of the experiment only two seedlings remained in the open and none in the grass. The results, however, are consistent with the previous cage exclusion experiment, where recruitment in grass was very low, even with exclusion of postdispersal seed predators (Table 2).

\section{Discussion}

The experiments summarized here suggest that seed predation and competition both had a negative impact upon the number of seedling plants recruited into the Platte thistle population. The effects of such sequential interactions in the life history can be cumulative in their effects on plant population density (Harper, 1977). In this case, early feeding by insects reduced the release of viable seed threefold, the establishment of seedlings sixfold, and the production of new adults sixfold compared to the water-sprayed plants and 37-fold compared to the nonsprayed plants (Table 1). Note that excluding insects led to much higher seedling recruitment and plant density without any alteration of existing levels of safe sites, postdispersal seed predation, or competition. Our results are consistent with other studies that have actually tested the role of insects in plant recruitment in natural habitats, i.e., in: woodland (Cantlon, 1969), tall grass prairie (Platt et al., 1974; Kinsman and Platt, 1984), deserts (Parker and Root, 1981; Parker and Salzman, 1985) and coastal chaparral (Louda, 1982a, b, 1983, 1988).

Postdispersal seed predation added to, but did not alter, the main impacts of predispersal feeding by insects. Vertebrates had more effect on seedling establishment in the open disturbed areas than in the more stabilized hillside vegetation; however, the proportion of seeds establishing seedlings was low even when postdispersal seed-feeders were excluded (Table 2). These results appear to contrast with findings for two other thistles, i.e., Cirsium palustre (van Leeuween, 1983) and C. vulgare (van Leeuween, 1983; de Jong and Klinkhamer, 1988a, b; Klinkhamer and de Jong, 1988; Klinkhamer et al., 1988; Silvertown and Smith, 1989). For these other thistles consumption of postrelease seed by vertebrates was high and it appeared critical in the determination of plant abundance.

Further, based on both the exclusion experiment in the grass-dominated area (Table 2) and the small-scale transplant of seedlings into grass clones (Table 3), we infer that com- 
petition seriously reduces recruitment of Platte thistle in the vegetated portion of the habitat (Table 3). Competition with other plants also appears to be an important factor in the establishment and dynamics of Bull thistle Cirsium vulgare (Austin et al., 1988; de Jong and Klinkhamer, 1988a; Klinkhamer and de Jong, 1988). The exact mechanism of interaction is unknown for Platte thistle. Water (e.g., de Jong and Klinkhamer, 1988b), light availability (C. E. Umbanhower, pers. comm.) or the combination of physical conditions (Solbeck and Sillen-Tullberg, 1986a, b) could limit the survival of new seedlings. Both water and light should be lower within the grass clone than in the open between clones. Soil water availability is the most likely mechanism in our system since water is often limiting for plant growth in Sandhills prairie (Barnes et al., 1984; Potvin and Harrison, 1984).

These data supplement the few studies in which both predation and competition have been studied concurrently. In addition, we add to the few data that are available on the effect of seed consumption on subsequent stages in plant population dynamics. Most previous studies that include both competition and predation have been done either in the greenhouse or, if done in the field, seedling establishment and subsequent survival were not recorded (see Louda et al., 1989). Both the data here and those of previous studies (e.g., Sibma et al., 1964; Windle and Franz, 1979; Fowler and Rausher, 1985; Parker and Salzman, 1985; Cottam, 1986; Cottam et al., 1986) suggest that invertebrate herbivory can contribute significantly to the determination of competitive outcome.

We conclude that predation, especially insect feeding that severely reduces seedling density, limits the abundance of Platte thistle and that competition with established plants may confine the distribution of most of the surviving individuals to open disturbed areas. Both processes should thus reinforce each other in selecting for a fugitive life history for Platte thistle.

Acknowledgments. - We thank the many people who have helped in the field on this project, especially Brett Anderson, Reena Batra, Suzie Cudmore, Duane Fritzen, Valerie Jones, Rod Otley, Carla Stephenson, Jim Smith and Jayne Stratton. We also appreciate the encouragement, challenge and help provided by our colleagues as this project developed, particularly Paulette Bierzychudek, Joe Connell, Tony Joern, Steve Jones, Kathleen Keeler, Bill Lamp, Rod Otley and Jim Stubbendick. The work was funded by a Grant-in-Aid from the University of Nebraska Research Council, supplemented by N.S.F. support to S.M.L. (BSR84-05625, BSR87-04705).

\section{Literature Gited}

ANDERSEN, A. N. 1988. Insect seed predators may cause far greater losses than they appear to. Oikos, 52:337-340.

1989. How important is seed predation to recruitment in stable populations of long-lived perennials? Oecologia (Berl.), 81:310-315.

Austin, M. P., L. F. M. Fresco, A. O. Nicholls, R. H. Groves and P. E. Kaye. 1988. Competition and relative yield: estimation and interpretation at different densities and under various nutrient concentrations using Silybum marianum and Cirsium vulgare. J. Ecol., 76:157-171.

Barnes, P. W., A. T. Harrison AND S. P. Heinisch. 1984. Vegetation patterns in relation to topography and edaphic variation in Nebraska Sandhills prairie. Prairie Nat., 16:145-158.

Cantlon, J. E. 1969. The stability of natural populations and their sensitivity to technology. Brookhaven Symp. Biol., 22:197-205.

CotTaM, D. A. 1986. The effects of slug-grazing on Trifolium repens and Dactylis glomeratea in monoculture and mixed sward. Oikos, 47:275-279.

- J. B. Whittaker AND A. J. C. Malloch. 1986. The effects of chrysomelid beetle grazing and plant competition on the growth of Rumex obtusifolius. Oecologia (Berl.), 70:452-456. 
CraWley, M. J. 1983. Herbivory, the dynamics of animal-plant interactions. University of California Press, Berkeley. 437 p.

- 1989. Insect herbivores and plant population dynamics. Ann. Rev. Entomol., 34:531-564.

Fenner, M. 1985. Seed ecology. Chapman and Hall, New York. 151 p.

Foster, S. A. 1986. On the adaptive value of large seeds for tropical moist forest trees: a review and synthesis. Bot. Rev., 52:260-299.

FOWLER, N. L. AND M. D. RAUSHER. 1985. Joint effects of competitors and herbivores on growth and reproduction in Aristolochia reticulata. Ecology, 66:1580-1587.

Gurevitch, J. 1986. Competition and the local distribution of the grass Stipa neomexicana. Ecology, 67:46-57.

Harper, J. L. 1977. Population biology of plants. Academic Press, New York. 892 p.

Harrington, H. D. 1954. Manual of the plants of Colorado. Sage Books, Denver. 666 p.

HendRIX, S. D. 1989. Seed predation, p. 246-263. In: J. Lovett-Doust (ed.). Plant reproductive ecology. C. R. C. Press, Boca Raton, Florida.

Janzen, D. H. 1971. Seed predation. Annu. Rev. Ecol. Syst., 2:465-492.

Jong, T. J. DE AND P. G. L. KLinkhamer. 1988a. Population ecology of the biennials Cirsium vulgare and Cynoglossum officinale in a coastal sand-dune area. J. Ecol., 76:366-382.

— AND — . 1988b. Seedling establishment of the biennials Cirsium vulgare and Cynoglossum officinale in a sand-dune area: the importance of water for differential survival and growth. J. Ecol., 76:393-402.

KeEler, K. H., A. T. HARrison AND L. S. Vescio. 1980. The flora and Sandhills prairie communities of Arapaho Prairie, Arthur County, Nebraska. Prairie Nat., 12:65-78.

Kinsman, S. AND W. J. Platt. 1984. The impact of herbivores (Heliodines nyctaginella: Lepidoptera) upon Mirabilis hirsuta, a fugitive prairie plant. Oecologia (Berl.), 65:2-6.

Klinkhamer, P. G. L. AND T. J. DE JoNG. 1988. The importance of small-scale disturbance for seedling establishment in Cirsium vulgare and Cynoglossum officinale. J. Ecol., 76:383-392.

- - AND E. VAN DER MEIJDEN. 1988. Production, dispersal and predation of seeds in the biennial Cirsium vulgare. J. Ecol., 76:403-414.

LAMP, W. O. 1980. Predispersal seed predation of the Platte thistle and its effect on seed production. Ph.D. Thesis, University of Nebraska, Lincoln. 173 p.

and M. MaCarty. 1981. Biology and ecology of the Platte thistle (Cirsium canescens). Weed Sci., 29:686-692.

AND - 1982a. Predispersal seed predation of a native thistle, Cirsium canescens. Env. Entomol., 11:847-851.

- AND - 1982b. Biology of predispersal seed predators of the Platte thistle, Cirsium canescens. J. Kans. Entomol. Soc., 55:305-316.

Lawson, M. D., K. F. Dewey AND R. E. Nield. 1977. Climatic atlas of Nebraska. University of Nebraska Press, Lincoln. 88 p.

LEEUWEen, B. H. VAN. 1983. The consequences of predation in the population of the monocarpic species Cirsium palustre and Cirsium vulgare. Oecologia, 58:178-187.

LoudA, S. M. 1982a. Limitation of the recruitment of the shrub Haplopappus squarrosus (Asteraceae) by flower- and seed-feeding insects. J. Ecol., 70:43-53.

1982b. Distribution ecology: variation in plant recruitment over a gradient in relation to insect seed predation. Ecol. Monogr., 52:25-41.

- 1983. Seed predation and seedling mortality in the recruitment of a shrub, Haplopappus venetus (Asteraceae), along a climatic gradient. Ecology, 62:511-521.

1988. Insect pests and plant stress as considerations for revegetation of disturbed ecosystems, p. 51-67. In: J. Gairns (ed.). Rehabilitating damaged ecosystems, vol. 2. C. R. C. Press, Boca Raton, Florida.

1989. Predation in the dynamics of seed regeneration, p. 25-51. In: M. A. Leck, V. T. Parker and R. L. Simpson (eds.). Ecology of soil seed banks. Academic Press, New York.

, K. H. KeEler AND R. D. Holt. 1989. Herbivore influences on plant performance and competitive interactions, p. 413-444. In: J. B. Grace and D. Tilman (eds.). Perspectives in plant competition. Academic Press, New York. 
Parker, M. A. AND R. B. Root. 1981. Insect herbivores limit habitat distribution of a native composite, Machaeranthera canescens. Ecology, 62:1390-1392.

- AND A. G. SAlzMAN. 1985. Herbivore exposure and competitor removal: effects on juvenile survivorship and growth in the shrub, Gutierrezia microcephala. J. Ecol., 73:903-913.

Platt, W. J., G. R. Hill and S. Clark. 1974. Seed production in a prairie legume (Astragalus canadensis $\mathrm{L}$.): interactions between pollination, predispersal seed predation and plant density. Oecologia (Berl.), 17:55-63.

Potvin, M. A. 1984. Factors affecting native grass seedling establishment along topographic gradients in the Nebraska Sandhills: an experimental approach. Ph.D. Thesis, University of Nebraska, Lincoln. 154 p.

1988. Seed rain on a Nebraska Sandhills prairie. Prairie Nat., 20:81-89.

AND A. T. HARRISON. 1984. Vegetation and litter changes of a Nebraska Sandhills prairie protected from grazing. J. Range Manage., 37:55-58.

Price, M. V. ANd S. H. Jenkins. 1987. Rodents as seed consumers and dispersers, p. 191-235. In: D. R. Murray (ed.). Seed dispersal. Academic Press, Sydney, Australia.

Risser, P. G., E. G. Birney, H. D. Blocker, S. N. May, W. J. Parton and J. A. Wiens (eds.). 1981. The true prairie ecosystem. U.S./I.B.P. Synthesis Series, Vol. 16. Hutchinson and Ross, Stroudsburg, Pa. 557 p.

SibMA, L., J. KorT AND C. T. DE Wit. 1964. Experiments on competition as a means of detecting possible damage by nematodes. Jahrb. Inst. Biol. sch. Landb. Wass., 1964:119-124.

Silvertown, J. AND B. SMITH. 1989. Germination and population structure of spear thistle Cirsium vulgare in relation to experimentally controlled sheep grazing. Oecologia (Berl.), 81:369-373.

Solbeck, G. AND B. Sillen-Tullberg. 1986a. Seed production and seed predation in a patchy and time-varying environment. Oecologia (Berl.), 71:51-58.

AND - 1986b. The role of variable weather for the dynamics of a seed-seed predator system. Oecologia (Berl.), 71:59-62.

Tolstead, W. L. 1942. Vegetation in the northern part of Cherry County, Nebraska. Am. Midl. Nat., 28:475-481.

United States Department of Agriculture, Soll Conservation Service. 1977. Soil survey of Arthur and Grant counties, Nebraska. U.S. Government Printing Office, Washington, D.C. $50 \mathrm{p}$.

Weaver, J. E. 1965. The native vegetation of Nebraska. University of Nebraska Press, Lincoln. $185 \mathrm{p}$.

WEBER, W. A. 1987. Colorado flora: western slope. Colorado Associated University Press, Boulder. $529 \mathrm{p}$.

White, J. 1980. Demographic factors in populations of plants, p. 21-48. In: O. T. Solbrig (ed.). Demography and evolution in plant populations. University of California Press, Berkeley.

Windle, P. N. AND E. H. Franz. 1979. The effects of insect parasitism on plant competition: greenbugs and barley. Ecology, 60:521-529. 